
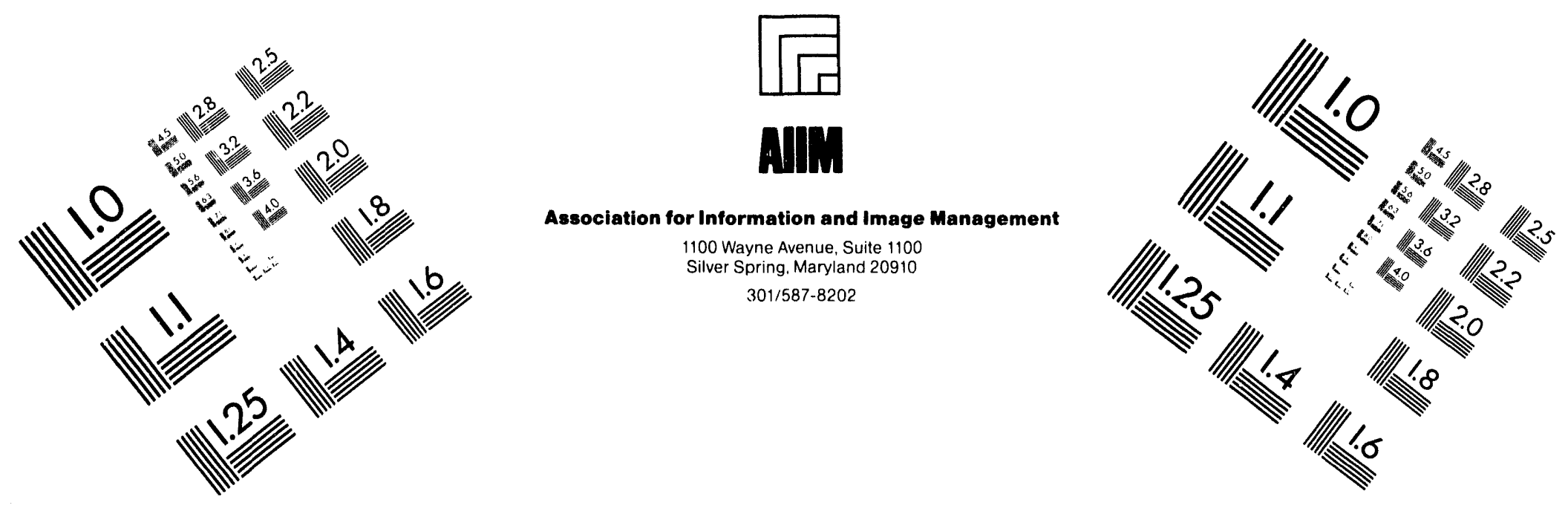

\title{
Centimeter
}

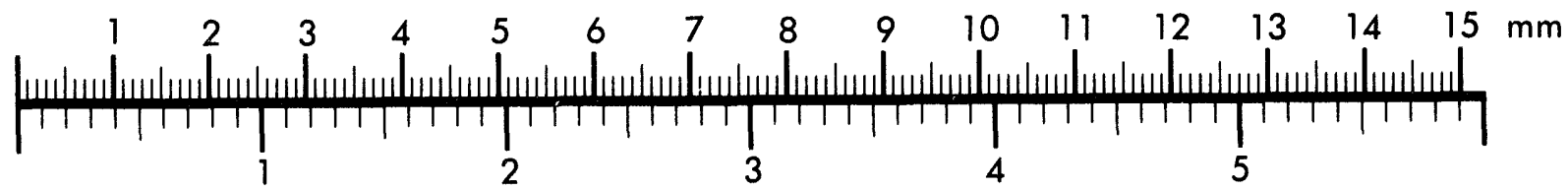

Inches
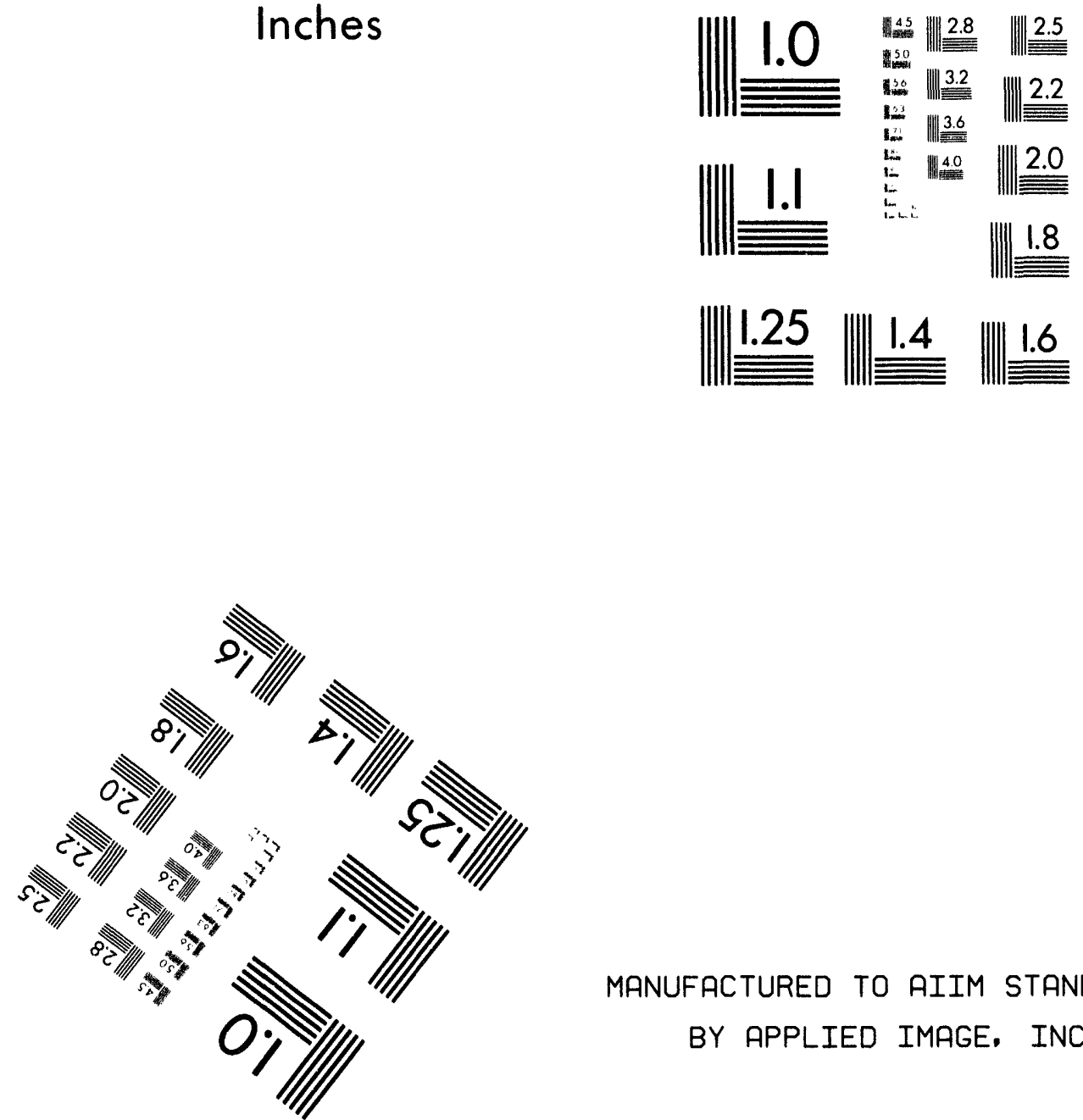

MANUFACTURED TO AIIM STANDARDS

BY APPLIED IMAGE. INC.

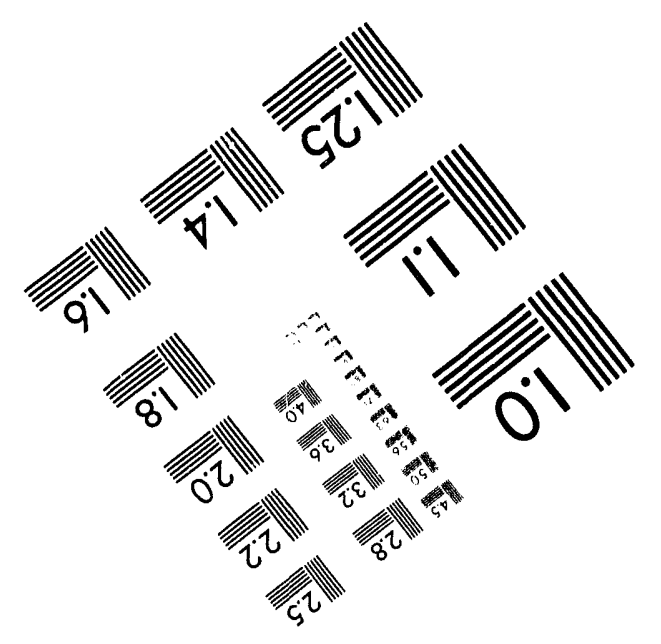



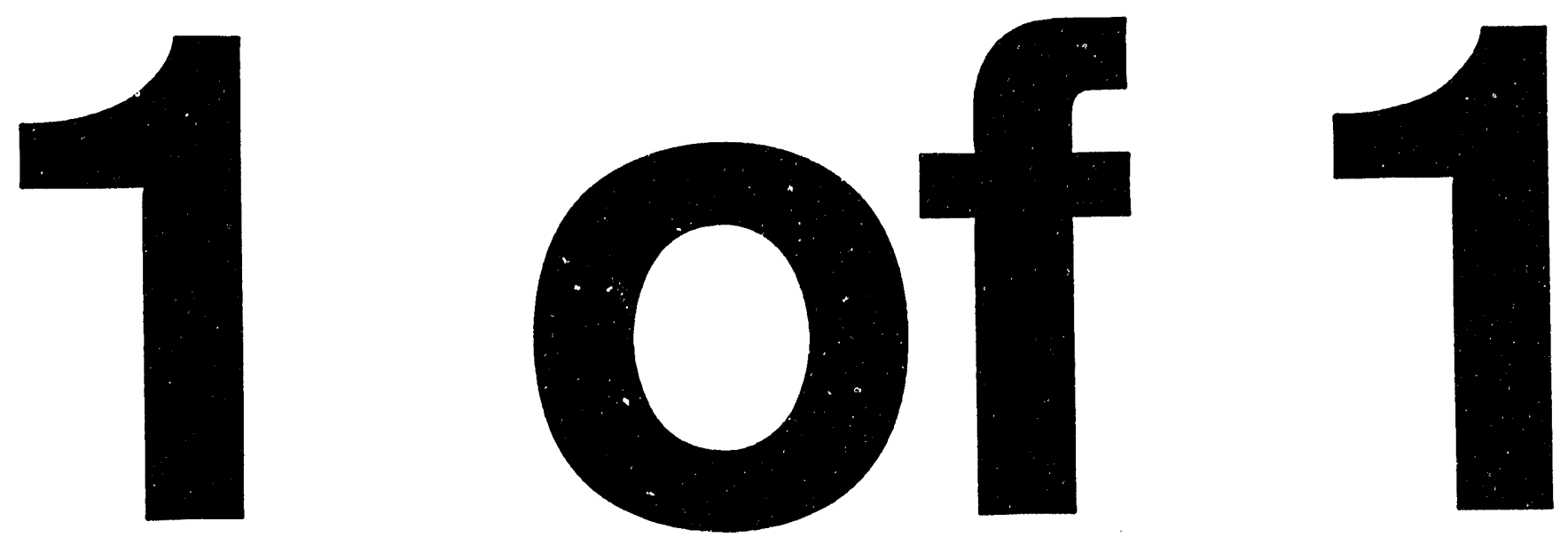
WHC-SA-2292łFP

\section{In Situ Radiological Characterization to Support an Excavation of a Liquid Waste Disposal Site}

B. D. Keele

Date Published

May 1994

To Be Presented at

1994 Symposium on Radiation

Measurements and Applications

Ann Arbor, Michigan

May 16-19, 1994

Prepared for the U.S. Department of Energy Office of Environmental Restoration and Waste Management

\section{(2) Westinghouse Hanford Company Richiand, Washington 99352}

Hanford Operations and Engineerıng Contractor for the U.S. Department of Energy under Contract DE.AC06-87RL10930

Copyright License By acceotance or inis articio the oublisher analor recipient acknowiodges the U S Governments rignt to rotain a nonoxctusive. rovaty-liee license in and to any copyrignt covering this paper. 


\title{
IN SITU RADIOLOGICAL CHARACTERIZATION TO SUPPORT A TEST EXCAVATION AT A LIQUID WASTE DISPOSAL SITE
}

\author{
Brian D. Keele \\ Roy G. Bauer \\ Gordon R. Blewett \\ Gary L. Troyer
}

\begin{abstract}
An in situ radiological detection system was developed to support a small test excavation at a liquid waste disposal site at the Hanford Site in Richland, Washington. Instrumentation, calibration and comparisons to samples are discussed.
\end{abstract}


WHC-SA-2292-FP

This page intentionally left blank. 
WHC-SA-2292-FP

CONTENTS

1.0 INTRODUCTION . . . . . . . . . . . . . . . . . 1

2.0 GAMMA-RAY ASSAY . . . . . . . . . . . . . . . 1

3.0 BETA ASSAY . . . . . . . . . . . . . . . . 3

4.0 COMPARISON TO SAMPLES ......................... 3

5.0 CONCLUSION . . . . . . . . . . . . . . . . . . 4

6.0 ACKNOWLEDGEMENTS . . . . . . . . . . . . . . . . . . . . . 4

7.0 REFERENCES ......................... 7

\section{LIST OF FIGURES}

1 Radial Response, HPGe Detector . . . . . . . . . . . . . . . 2

2 Schematic of Concentric Rings for Determing Effective Area . . . . . . 2

3 Data Comparison for ${ }^{137} \mathrm{Cs}$. . . . . . . . . . . . . . . 5

4 Data Comparison for ${ }^{90} \mathrm{sr}$. . . . . . . . . . . . . . 6 
WHC-SA-2292-FP

This page intentionally left blank. 
WHC-SA-2292-FP

\section{IN SITU RADIOLOGICAL CHARACTERIZATION TO SUPPORT AN EXCAVATION OF A LIQUID WASTE DISPOSAL SITE}

\subsection{INTRODUCTION}

A mobile in situ radiological detection system was developed to support a test excavation of a liquid waste disposal site. Assay results were used to determine site closure and excavation boundaries, to track waste concentrations, and to evaluate instrumentation for use in future environmental remediation projects.

The early Hanford Site production reactors used the soil column for disposal of cooling water during fuel cladding failures. One of these abandoned disposal areas, called a "crib" was excavated as part of the Hanford Site environmental cleanup effort. Discharges to the crib ceased in 1952. The major isotopic constituents found were ${ }^{337} \mathrm{Cs}$ and ${ }^{90} \mathrm{Sr}$, the minor constituents were ${ }^{241} \mathrm{Am},{ }^{152} \mathrm{Eu},{ }^{154} \mathrm{Eu},{ }^{239} \mathrm{Pu}$ and ${ }^{240} \mathrm{Pu}$.

The instrumentation consisted of a 16 in. $x 4$ in. $x 4$ in. $N a I(T 1)$ detector, a $35 \%$ hyperpure germanium detector (HPGe), and two types of plastic scintillator systems which were configured specifically for ${ }^{90} \mathrm{Sr}$ detection. The gamma-ray detectors were collimated with lead and were mounted on a trailer at a height of $22 \mathrm{in.}$ The beta detectors were manually placed in direct contact with the ground.

\subsection{GAMMA-RAY ASSAY}

Four inch thick spiked soil standards were placed one inch below the collimator opening for calibration. Extrapolations to infinite soil depth was accomplished by determining the ratio of calculated radiation fluxes for both a finite thickness standard and an infinitely thick soil, in a manner somewhat similar to the method that (Reed 1973) used for calibration in the assay of large buriel boxes. The flux was calculated at the center of the detector using the MICROSHIELD ${ }^{1}$ computer program.

A truncated cone geometry was used to approximate the source and collimated detector. The apex angle of the truncated cone was determined from the effective area. The radial response of the HPGe detector, shown in Figure 1 , was determined by counting a point source moved at set intervals. For determination of the effective area (Russo 1987), the net counting rate of each location in Figure 1 is multiplied by the area of a concentric ring as shown in Figure 2. These factors are normalized and summed. The apex angle for the 16 in. $x 4$ in. $\times 4$ in. detector was determined from the average effective area of the long and short axis of the crystal.

1 Microshield is a registered trademark of Grove Engineering. 
Figure 1. Radial Response, HPGe Detector.

\section{Radial Response, HPGe Detector $110 u \mathrm{ui}^{137} \mathrm{Cs}$ Source at 22 Inches}

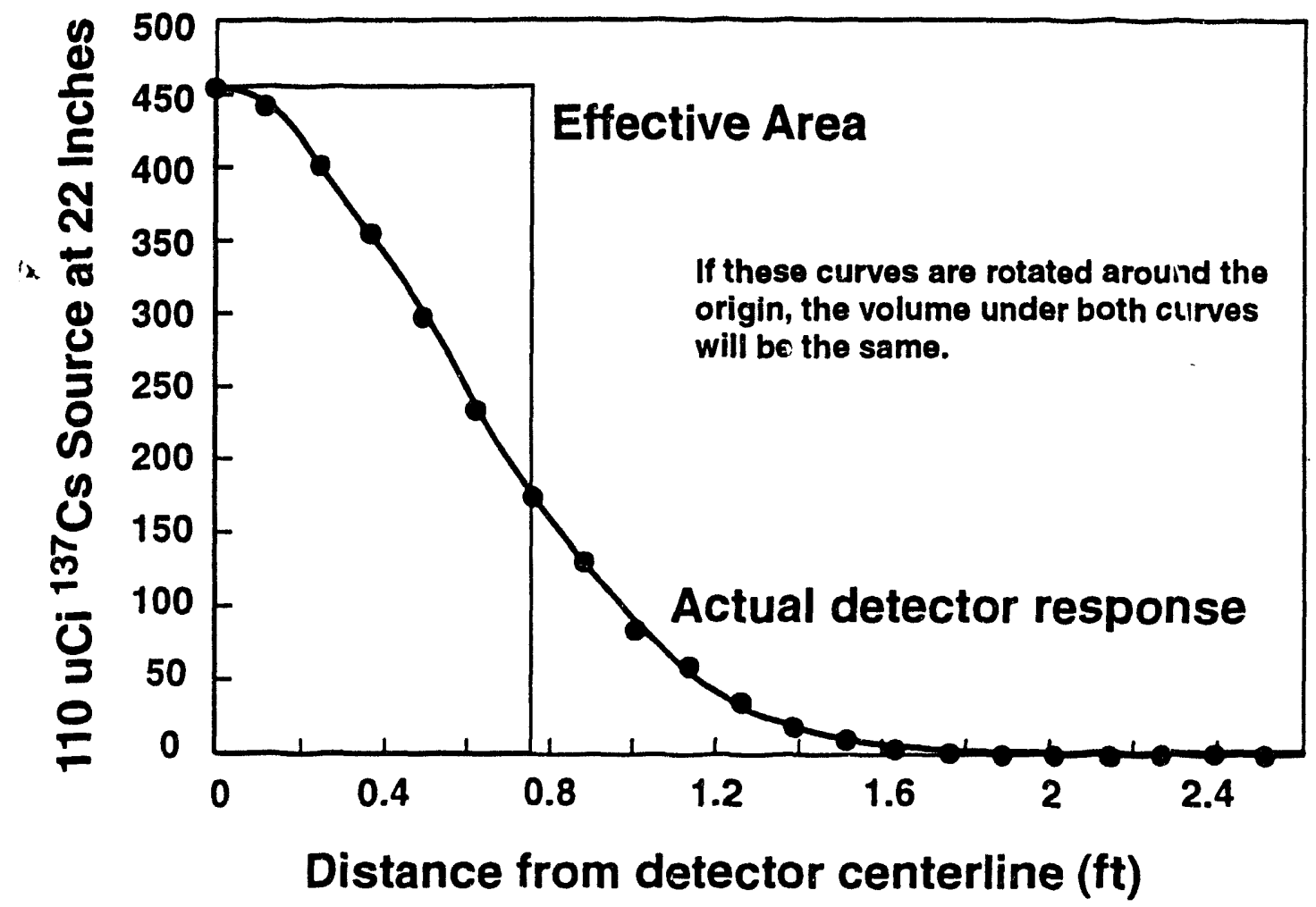

Figure 2. Schematic of Concentric Rings for Determing Effective Area.

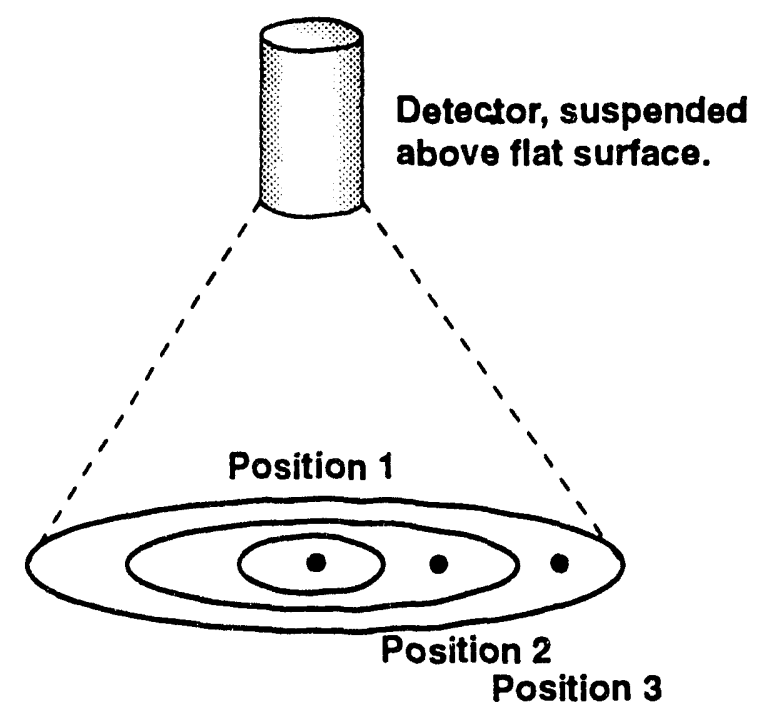


A significant source of localized background originated from "hot spots" located adjacent to assay locations. Non-assay point gamma rays would reach the detector from adjacent sources by traversing the lead shield of the collimator. The signal from this type of background was determined by placing lead over the collimator opening (Kindle 1976).

\subsection{BETA ASSAY}

One of the two beta detectors was $1 / 4$-inch by 10 -inch-diameter plastic scintillator coupled to a standard photomultiplier tube (PMT). ${ }^{90} \mathrm{Y}$ (a daughter of ${ }^{90} \mathrm{Sr}$ ) was determined from a region-of-interest from 0.8 to 2.3 $\mathrm{MeV}$, which was chosen to be above the energy of conversion electrons from ${ }^{137}$ Cs.

The other beta detector was a prototype fiber-optic detector developed by Pacific Northwest Laboratories (Abe1 1994). It is constructed of three 1-mmthick scintillating layers. When a beta particle is energetic enough to penetrate a11 three layers, such as those from ${ }^{90} \mathrm{Y}$, the event is counted as a real event. When lower energy beta particles do not have enough energy to penetrate all three layers the event is rejected. Gamma rays will not necessarily interact within all three layers, and will not likely be counted. Both detectors were calibrated with spiked sand.

There were uncertainties relating to the reliability of the beta results. Originally, the rocks were to be raked aside and the detectors placed directly on the sand. This was not feasible because Hanford Site soil is similar to a rocky river bed and the rocks could not easily be raked aside. The soil matrix at the excavated crib was approximately $80 \%$ rock and $20 \%$ sand. In addition, the highest levels of activity were unexpectedly found on and within pourous basaltic river rocks, not in the sand.

\subsection{COMPARISON TO SAMPLES}

Verification of the system was attempted through sampling and laboratory analysis. A significant field problem was the collection of representative soil samples for comparative data. Depending on the location, the contamination was preferrentially affixed to the surfaces of the rocks, or concentrated in the sand. The activity was non-uniformly dispersed, and several orders of magnitude changes in activity levels were noted over a distance of one half meter. Because the soil sampling was limited to fine grained material, it was difficult to obtain a $500 \mathrm{ml}$ sample that was representative of the large volume of rocky soil that was characterized using in situ techniques.

Comparisons between in situ analysis and laboratory analysis are shown in Figures 3 and 4 for ${ }^{137} \mathrm{Cs}$ and ${ }^{90} \mathrm{Sr}$, respectively. The first number of the location code is the excavation number, the larger the number the deeper the 
excavation lift. The letter refers to the direction north, south, east, or west of the center point, which is designated as zero. The last number refers to the distance in yards from the center of the crib.

Hand-held health physics instrumentation determined that the contamination was normally affixed to the rocks near the point of discharge into the crib. As the distance from the discharge point increased, the activity was preferrentially concentrated in the sand.

At locations where the activity is concentrated in the sand, it is to be expected that the analysis of the samples would yield an activity that is approximately five times greater than the in situ measurements (because of the $80 \%$ rock content). The ratio is expected to drop at locations where a greater porportion of activity is located on the rocks.

The data of Figures 3 and 4 is consistant with the trends observed with the hand-held instrumentation. Point 2:S1, located immediately below the discharge into the crib, shows the in situ measurement to be much higher than the laboratory sample due to the deposition on the rocks.

The best way to compare in situ techniques to laboratory verifiable samples is through analysis of uniformly distributed natural isotopes. The HPGe detector was calibrated using a mixed gamma-ray source, not directly with natural emitting isotopes. Laboratory and in situ measurements showed the average $\mathrm{K}-40$ content was 14.0 and $15.6 \mathrm{pCi} / \mathrm{g}$ and the average ${ }^{232} \mathrm{Th}$ daughter concentration of the last $1 \mathrm{ift}$ was and $0.76 \mathrm{pCi} / \mathrm{g}$ and $0.83 \mathrm{pCi} / \mathrm{g}$ (238 keV), respectively.

\subsection{CONCLUSION}

This project demonstrated the utility of in situ radiological characterization. The technique was able to adequately characterize soil activity when radionuclides were dispersed in a nonhomogeneous fashion. Reliability of the gamma-ray technique was indicated by analysis of the natural occuring radionuclides. In situ characterization has provided more reliable inventory of radiological materials than traditional sampling in conjunction with laboratory analysis due to averaging activity over a larger volume of soil and inclusion of the rocks. Plans are underway to make use of similar instrumentation for future environmental remediation activities.

\subsection{ACKNOWLEDGEMENTS}

We would like to thank Dave Blumenkranz and Jil Frain for coordinating all aspects of this project, and Alan Schilk of Pacific Northwest Laboratories for developing and suppiying the fiber-optic beta detector. 
WHC-SA-2292-FP

Figure 3. Data Comparison for ${ }^{137} \mathrm{Cs}$.

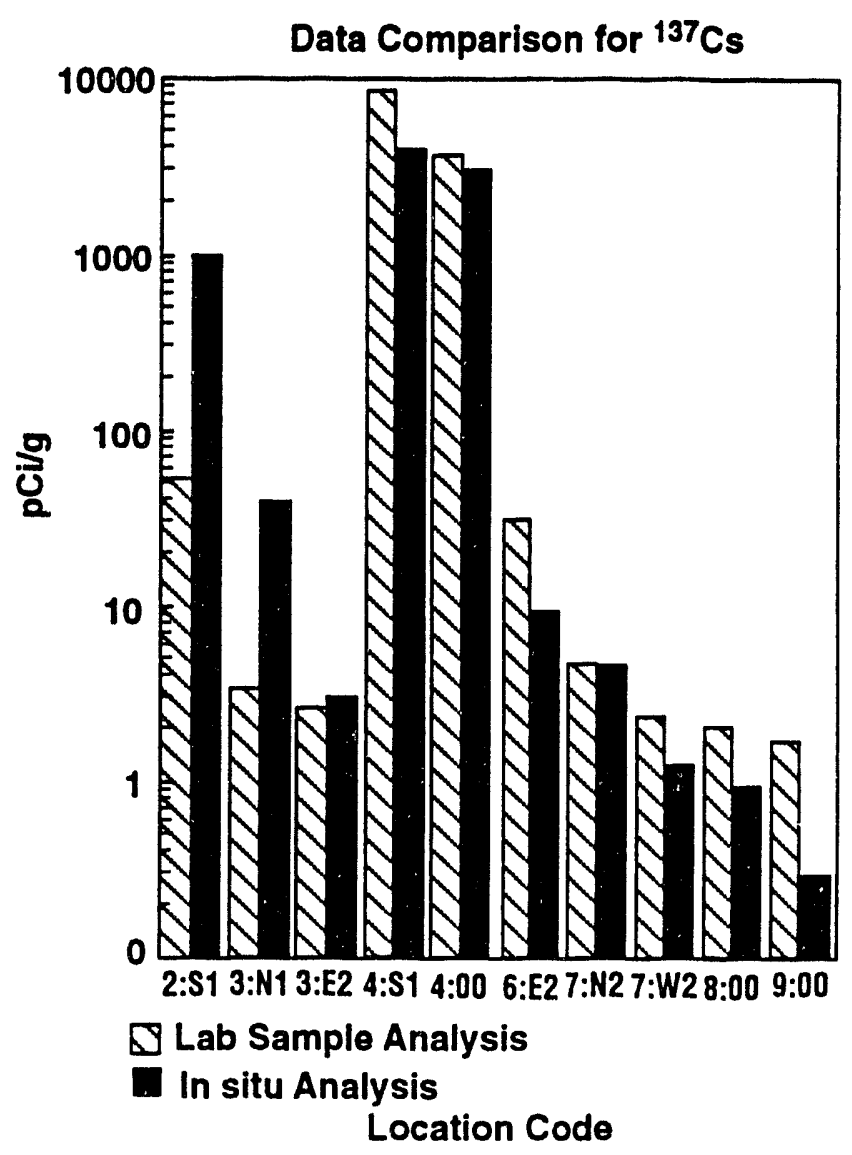


Figure 4. Data Comparison for ${ }^{90} \mathrm{Sr}$.

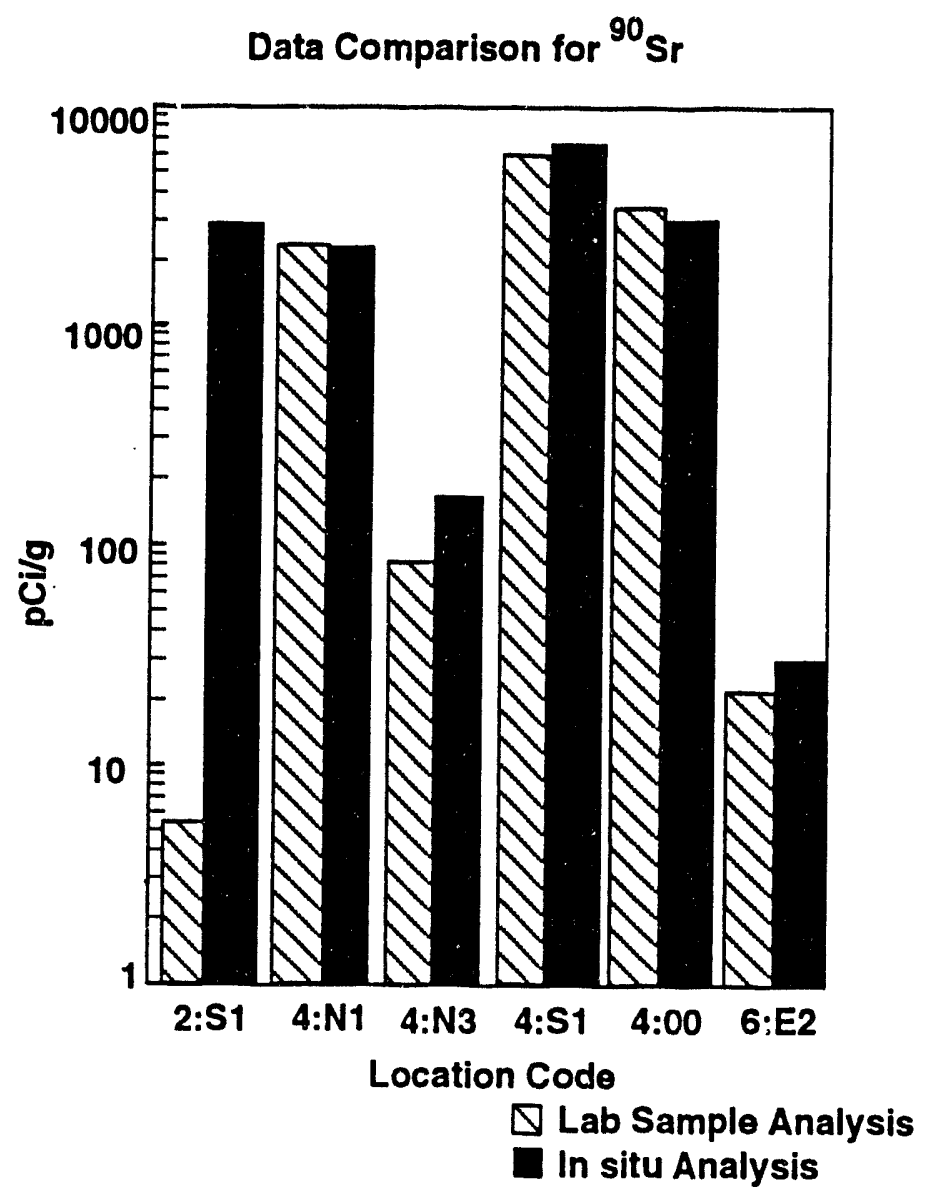




\section{WHC-SA-2292-FP}

\subsection{REFERENCES}

W. D. Reed Ji., J. P. Andrews, and H. C. Keller, "A method for surveying for ${ }^{235} \mathrm{U}$ with Limit of Error Analysis," Nuclear Materials Management, Vol. 2, (1973), 395.

P. A. Russo, J. K. Sprinkle, Jr., and T. H. Elmont, "Holdup Measurements of the Rocky Flats Plant 371 Precipitator Canyons, "Report LA-10967-MS, April 1987, , U.S. Department of Commerce, Springfield, Virginia.

C. H. Kindle, "In Situ Measurement of Residual Plutonium", Journal of the Institute of Nuclear Materials Management, V(5), (June 30, 1976), 540-549.

K. H. Able, A. J. Schilk, D. P. Brown, R. C. Thompson, and R. W. Perkins, "Characterizacion and Calibration of a Large Area Beta Scintillation Detector for Determination of ${ }^{90} \mathrm{Sr}, "$ Third International Conference on Methods and Applications of Radioanalytical Chemistry, April 10-16, 1994 , Kona, Hawai i. 


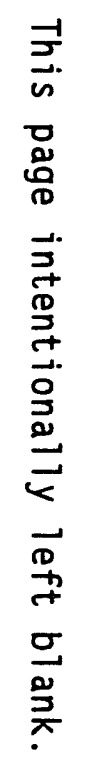

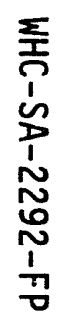

$\stackrel{7}{7}$

꽂 
WHC-SA-2292-FP

\section{DISTRIBUTION}

Number of Copies

\section{ONSITE}

5

95

\section{U.S. Department of Energy}

E. D. Goller (5)

A5-19

Westinghouse Hanford Company

Document Processing and Distribution

L8-15

Information Release Administration (3)

R. G. Bauer

L. M. Bergmann

G. R. Blewett

D. B. Blumenkranz

J. E. Darling

D. A. Dodd

J. M. Frain

D. R. Jordan

B. D. Keele (74)

C. H. Kindle

J. E. King

L. D. Lockard

L. L. Lockrem

C. S. McClelien

A. J. Schilk

C. R. Stallbaum

G. L. Troyer

J. G. Woolard
R1-05

H6-05

H6-05

S3-90

H6- 04

S3-90

T6-50

H6-04

$\times 2-10$

S3-90

B5-32

S3-90

S3-90

S3-90

H6-04

P8-01

T5-05

T6-50

H6-05 

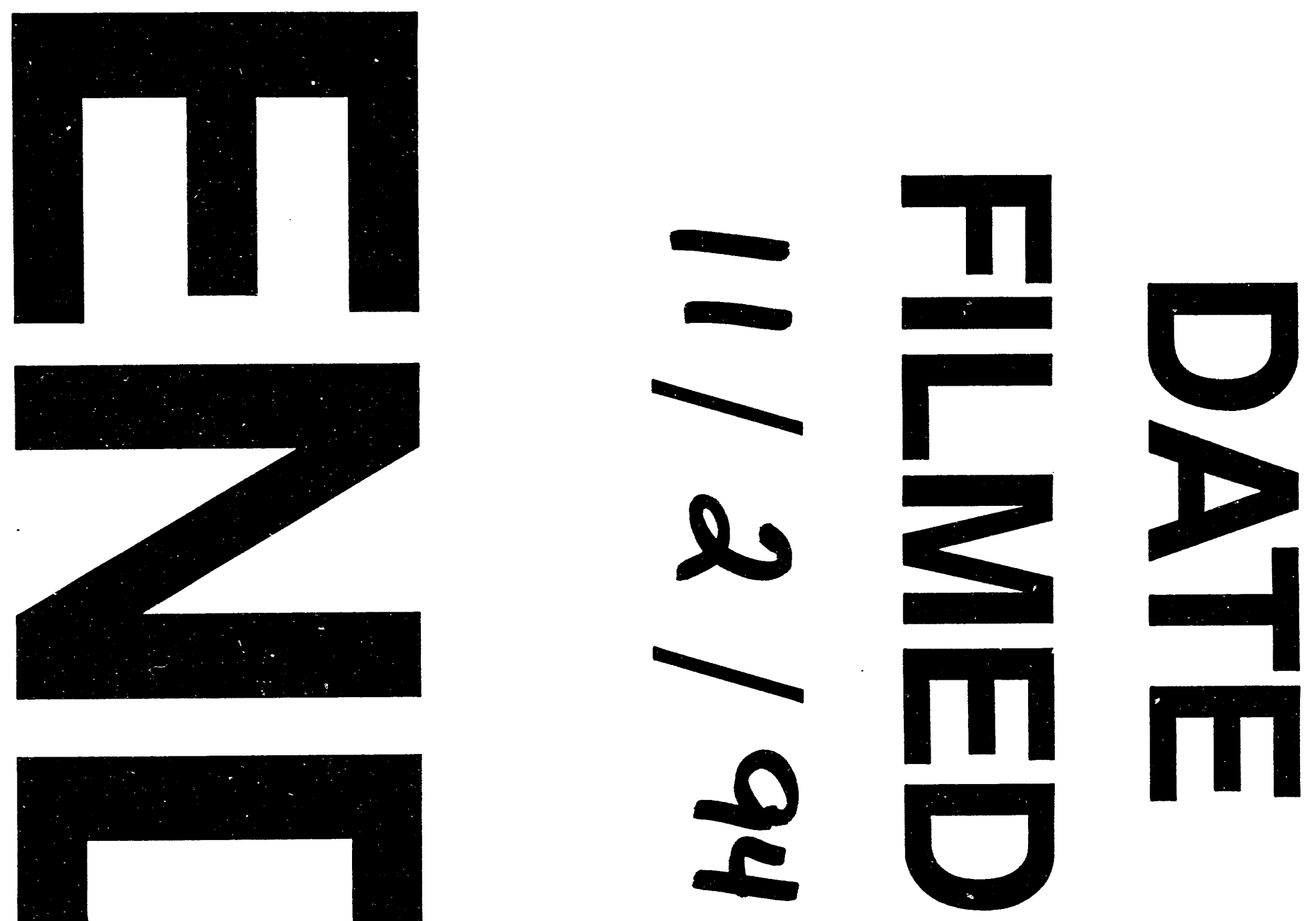
